\title{
Values Education from Perspectives of Classroom Teachers
}

\author{
Nil Duban \\ Afyon Kocatepe University, Assoc. Prof. Dr., \\ Bülent Aydoğdu
}

Afyon Kocatepe University, Assoc. Prof. Dr.,

\begin{abstract}
Values education is a process, which begins at home and continues in society and in formal education institutions. The purpose of this research is to determine the opinions of primary school teachers about values education in primary schools. In the current research, the qualitative research method and focus group interview technique were used. The participants of the study were eight classroom teachers who were pursuing master's degree at the classroom education program of Afyon Kocatepe University. The participants were selected using the intense case sampling, which is part of purposeful sampling technique. The data were collected through audio-taped group interview. The credibility of this study was enhanced by expert review. The interview schedule was sent to experts for review. The trustworthiness of this study was established by the formula proposed by Miles and Huberman. It was calculated as 0.92 . The data collected from the interview were examined using a qualitative data analysis approach. The findings of the study showed that if value education starts at early ages it would provide much more opportunity to prepare for future life, to improve personality and to have long-lasting values. The participants argued that parents are very significant in value education. The participants suggested that value education should be either an independent course or certain values should be taught in existing courses. They also proposed that in value education case studies and drama can be used and that positive and desired behaviours and empathy should be encouraged among children.
\end{abstract}

Keywords: Values, Values education, Teachers, Primary Schools, Primary school students.

\section{Introduction}

Value education is a process, which begins at home and continues in society and in formal education institutions (Başçı, 2012). In recent days the significance of values and having certain values have been emphasized (Özdaş, 2013). Given that values play a significant role in social life educational systems cover value education and it may be either through independent courses or through integration of values in different courses in the educational programs. On the other hand, educational institutions transfer values to students, which is one of the ways of socialization (Güngör, 1998). Therefore, teachers play a significant role in this regard. It is certain that in order to fulfil this specific role teachers should assimilate those values to be taught to students (YIImaz, 2010). On the other hand, values have a significant effect on teachers' educational decisions and acts (Fasheh 1982). Values are related to the perception of anything as important or not important. For instance, a math teacher may or may not attach importance to reasoning, problem-solving or the use of technology in courses (Seah 2002). Values allow for individuals to understand what are prior and what are not. On the other hand, values should be taught at home and at formal education institutions (Bridge, 2003). If an educational approach which supports only cognitive and psycho-motor competence is adopted, then students cannot acquire affective gains which include values of the society (Baysal, 2013). Therefore, value education should be emphasized both at home and in schools. 
There are many distinct definitions of values. In addition, Brown (2001) argued that it is not easy to define what value is. Turkish Language Association defined value as follows: "(value) is an abstract criterion to understand the significance of something" (www.tdk.gov.tr). Raths, Harmin and Simon aregued that values are general guides for behaviours, which are resulted from personal experiences (1987; cited in Seah \& Bishop 2000). Swadener and Soedjadi (1988) regarded values as a concept or an idea, which is about the value of something. Sağnak (2004) stated that values are beliefs about individuals' ideal behaviour or their purpose of life, or multi-dimensional standards, which guide their behaviour.

There is limited number of educational studies dealing with values (Bishop, Fitz Simons, Seah, \& Clarkson 1999; Seah \& Bishop 2000). Although there are references to values in general educational goals of the ministry of national education and in general goals for primary education programs and secondary education programs, in Turkey there are no intensive studies on value education. In one of rare studies on value education Turkey Ateş (2013) revealed the views of primary school teachers and secondary education teachers about value education and the related teaching activities. The findings of the study showed that for the majority of the teachers sampled value education is needed and that families are not very powerful in promoting values, leaving it to schools without any support from media, non-governmental organizations. Baysal (2013) also analysed value education in Turkey and found that those teachers participated in value education-related seminars are much better in the use of materials in contrast to those who did not participate in such seminars or activities. It was also concluded that for teachers with parental involvement value education could be much more productive. ÖzalpKaplan (2014) argued that value education should be delivered in a specific course in which necessary sources and materials are used and that value education should be delivered with coordination between school, parents, society. Therefore, teachers should be informed about value education through in-service training activities. On the other hand, the perspectives of teachers about value education should be uncovered. Based on this assumption, the study aims at revealing the views of classroom teachers about the problems related to value education activities. In parallel to this aim the study attempts to answer the following research questions:

\section{What do classroom teachers think about the necessity of value education for primary school students?}

2. What do classroom teachers think about the contributions of parents to value education?

\section{What do classroom teachers think about the process of value education in schools?}

4. What do classroom teachers think about value education in teacher training programs? What are their suggestions to improve it?

5. What do classroom teachers think about making value education more efficient in out of school contexts?

\section{Method}

\section{Design}

The study was designed as a qualitative research. It employs group interviews to collect the data. Group interviews are part of qualitative research approach. The goal of group interviews is to gather people together to express their views about a specific topic. Group interviews take shorter time to complete. It is mostly employed when the participants work for the common goal and the views of each participant is significant for other participants (Cohen, Manion, \& Morrison, 2007).

\section{Participants}

The participants of the study were classroom teachers who were pursuing master's degree at the classroom education program of Afyon Kocatepe University. The participants were selected using the intense case sampling, which is part of purposeful sampling technique. The intense case sampling is realized through the selection of those who have intense experience or views about the topic at hand (Schreiber \& Asner-Self, 2011). The participants took the courses of "contemporary approaches towards science and technology education" and "novice approaches towards social studies teaching". In both courses value education was studied and discussed. The total number of the participants was eight, five of whom were males. Two participants were novice classroom teachers. The other two had a one-year teaching experience. One of the participants had a three-year teaching experience. Another one had a seven-year teaching experience. The remaining two had a nine-year teaching experience. 


\section{Data collection tools}

The data of the study were collected through use of semi-structured interview forms. The interview form was developed by the author. It covered eight open-ended items. Internal validity of the interview form was established through the review of field specialists. A good field specialist review should deal with the question of whether or not the items are reasonable (Merriam, 2013). At the initial phase the interview form included ten open-ended items developed though the review of the related literature. The form was reviewed by three field specialists. They analysed the items in terms of the consistency of the coverage of the items and the understandability of the items. Based on the feedback of the specialists two items were excluded and the final form covered eight items. The items were asked to the participants in a face-to-face interview context.

\section{Data analysis}

The data collected from the interview were examined using a qualitative data analysis approach. Qualitative data analysis is mainly made up of coding the data, dividing the text into small units, using labels for each unit and grouping codes under themes. Code labels can be developed from either any word used by the participants, or any statement used by the researchers or any social scientific term (Creswell \& Plano Clark, 2014). The interview data recorded were transcribed. The authors independently reviewed these transcriptions and developed the categories. Then categories were developed based on codes. Lastly the related categories were combined and were placed under sub-themes.

Reliability in qualitative research refers to consistency of the reviews of multiple coders. Therefore, mutually agreed ones indicate the reliability (Creswell, 2012). In the study codes developed by the authors were compared to reveal those which were mutually agreed. In the reliability analysis the formula developed by Miles and Huberman (1994) was employed (reliability = mutual agreement $/$ (mutually agreement + disagrement). The reliability coefficient was found to be 0.92 .

\section{Findings}

Following the data analysis, it was found that there was one theme, value education process. This theme was found to have four different subthemes: Why early ages? Who are effective? what should be done? and What do the participants suggest? The subthemes were also found to include several categories. Table 1 shows the theme, sub themes and categories about value education found in the analysis.

\section{Findings about the sub theme of "why early ages?" in value education}

The participants mostly stated that value education should start at early ages. They argued that such a value education will help children to prepare for future life, to develop their personality, and to have long lasting attitudes and acts.

\section{Life preparation}

As stated earlier the participants thought that value education should start at early ages if it is to contribute to life preparation. One of the participants, Selçuk, stated "for me value education at primary school is important to prepare children for future life. It deals with life experience, perspectives and their attitude towards other people. I teach studnets in these topics to prepare them for future."

\section{Personality development}

The participants argued that value education at early ages is effective because it helps personality development. One of the participants, Vildan, explained it as follows: "some values can only be acquired at early ages and become part of personality. For instance, being respectful for elderly people. If it is not taught at early ages, they may not learn it later. So we as primary education teachers should deliver value education."

\section{Permanence}

The participants argued that skills and values learned at early ages will be long-lasting, therefore value education should be given at early ages. For instance, Ayçin stated the following view: "Value education should be given at the level of 
primary school. We have a related proverb, saying as the twig is bent so is the tree inclined. Therefore, some values should be acquired at early ages, making them long-lasting."

\section{Findings about the sub theme of "who are effective?" in value education}

In regard to the sub theme of "who are effective (in value education)?" three categories were found: teachers, parents and society. The participants stated that although value education is related to the society as a whole both parents, teachers and society have their own effects on value education.

\section{Parents}

It was stated that parents are very significant in value education since it is first given at home. One of the participants, Ümit, reported "value education begins before formal education process. Values are first taught by parents. But does it true for all parents? Not possible. Some parents are not interested in value education of their children. For instance, in rural areas parents do not have enough time to focus on value education. As a result, children have insufficient education on values such as respect, tolerance, fairness and honesty. This may be complemented by formal education institutions."

Another participant, Şerife, reported "when children come school they bring different cultural values to the school. They begin school with the values taught by the parents. Teachers try to teach different values. If parents cannot manage to teach values to children teachers cannot teach every single value to them. However, teachers are expected to manage it."

One of the participants, Burak, dealt with the negative effects of parents on value education as follows: "some parents do not support value education, instead they have negative effects on it. Fathers may learn how to swear to their children. Such negative behaviours are sometimes supported by peers. It is hard to change this behaviour and to them them that swearing is not desired in our culture." Therefore, in some cases parents have negative effects on value education.

\section{Society}

The participants argued that society has also effects on value education and that in order to have children with wellestablished values formal value education at schools should be supported by society. For instance, Harun stated "I think there are disadvantages in teaching values in Turkey. I am not sure that teachers could effectively teach such values as being honest, protecting environment. Although these are taught at schools, I think students do not practice them in daily life. In order to have an efficient value education it should be supported by society."

Another participant stated that everybody has a role in value education: "what we taught at schools is not reinforced by society. If it is reinforced, the goal can be achieved. Students come across very different situation society. I always tell my students that we must respect all living beings. One of my students saw a man who was broking the tree and warned him. That person exhibited very negative reaction what my student said. So he frustrated. I think he will not say the same again in similar situations."

\section{Teacher}

The participants stated that for school-age children teachers are the models. One of the participants, Ömer, stated "Teachers are the models for students. One day I went class late since I was talking to the administrator. I told my students that I was late because of that. I thnk giving such explanations is useful to make them honest. Because when tey are late for the class they can also say the reason for it honestly."

\section{Findings about the sub theme of "what should be done?" in value education}

\section{Value education courses in the educational program}

Some of the participants argued that value education course can be covered in the primary school education program. They stated that all necessary values can be taught more easily. For instance, Harun expressed his view as follows: "religious culture and ethics course is given at the fourth class. It is about some of the values. But if we have an independent value education course students can develop an awareness about values. Can we teach values in each course? I think it is hard because of time constraints. I think it is reasonable to have a separate course for value education." 


\section{Integration of value education with other courses}

There are other participants who argued that instead of having an independent course for value education, values can be taught in different existing courses. For instance, Ayçin, reprted that: "For instance, in life sciences course we taught such values as being respectful for their peers and others during the teaching of the democracy concept. In addition, in the Turkish language courses we teach other values including friendship, caring for other people while discussing related materials. While teaching divisions in mathematics course I encourage students to share what they have with their friends. Therefore, given that there is no independent course for value education we can use other courses to teach values whenever it is possible."

\section{Using cases}

The participants stated that in value education case studies can be employed. Such cases can be discussed in the class or can be used in drama activities. They also stated that if any student exhibited a positive behaviour he can be reinforced and can be given as an example for other students in classroom. One of the participants, Selçuk, stated "one of my students, Mehmet, accidently hurt another student while playing a game in the school yard. When he saw me he embrassed and escaped. Another student Emre brought the other student to toilet and washed his face. I said Mehmet that it was incorrect, since he should have brought him to toilet instead of Emre."

\section{Parental support}

One of the participants, Ömer, who believed that parental support is crucial for value education stated "if value education at schools are consistent with the values at home parents support it. Parents should be part of value education to increase the common values. For instance, parents can be informed about the values to be taught at school and they can be part of decision making process about which values should be integrated into the program. If children have experience about the same values at school and at home, learning will be long-lasting. It also facilitates value education."

In a similar vein another participant, Vildan reported "as Ömer argued it is in fact the education of parents. They should have contradictory ideas. If any value taught at school is not given importance at home teaching is not significant for students. For instance, if child is not part of decision making process at home, he cannot comprehend the value of democracy. And a contradiction occurs if it is taught at home. Therefore, parental support should be granted if value education is to be effective."

\section{Out of school activities}

The participants emphasized the fact that the task of value education is not solely responsibility of schools and that it should be shared with society. They suggested that activities should be designed with all related parties in value education.

One of the participants, Burak, stated "for instance in the town where I am working a project to avoid swearing was carried out. It was started by local administration and all people supported it. In the project using different devices such as brochures this value was emphasized and children became aware of it."

\section{Society based projects}

One of the participants, Selçuk, talked about another activity to maintain permanence of values: "In the school we have society based activities. We connect value education with such activities. There a widower living alon in the village. Students brought several materials for her. Some of the students visited her at home and they helped her. Out small scale activity reached its goal."

\section{Findings about the sub theme of "what do the participants suggest?" in value education}

\section{Teacher training programs}


The participants stated that teacher training programs do not have any subject dealing with the activities related to value education. For instance, Ömer stated "I have been a teacher for three years, I did not hear even the name of value education in the teacher training program. I heard it following my profession as a teacher. I which I got courses on it, because I could easily handle it. I had hard times to think about designing activities in value education."

\section{In-service training activities}

The participants suggested that insufficient knowledge base of teachers about value education may disappear if they participate in in service training courses on value education. They reported that in-service training activities about value education should include both theoretical information and practice. Such a training will assist them in teaching values. One of the participants, Harun, stated "If in in-service training activities we are given both theoretical information and practical knowledge about value education, we will experience problems in value education at minimal level."

\section{Project-based performance practices}

The participants suggested that in order to promote value education the projects developed by teachers may be rewarded and teachers may be given extra credits for their activities. For instance, Ümit stated his view as follows: "projects can be carried out in relation to value education. Such projects can be evaluated by inspectors. If it is found to be useful, either school or teacher may be given extra credit. It should be rewarded."

\section{Selection of teachers}

The participants argued that teachers should have the values to be taught. in the selection of teachers this point can be taken into consideration. For instance, Ayçin stated her view as follow: "teacher responsibility is very significant. Each step in teaching profession several criteria should be used to choose future teachers. I think it is the most significant part of the process." A similar view was expressed by another participant, Vildan: "The behaviour of student teachers should be followed. They can be tested in terms of values they have. Those who could not have a certain level should not be teacher."

\section{Results and Discussion}

The findings of the study showed that if value education starts at early ages it would provide much more opportunity to prepare for future life, to improve personality and to have long-lasting values. The participants argued that parents are very significant in value education. However, parents may either positive or negative effects on value education of their children. Lucas (2009) also emphasized the significance of parents and found that for teachers one of the significant actors in character education is parents. Ateş (2013) concluded that positive values taught by parents reinforce value education at schools, but if there is any contradiction between the values of parents and those emphasized at schools it is hard for teachers to teach the desired values. KIIlç Şahin (2010) also maintained that parents are very significant in value education and that value contradiction beyween home and school makes hard for teachers to teach the desired values. Similarly, Aslan (2007) found that the inability of teachers to teach basic skills, knowledge and values is directly related to the indifference of parents. All these findings are consistent with each other.

The findings of the current study also showed that social support is needed to make value education successful. RobinsonLee (2008) also reached a similar conclusion and emphasized that involvement of all related parties is needed for an effective character education. Cooperation of educators, school administrators, parents and society members should exist if the values taught to be effective and all these parties should be informed about character education.

In the study it was also found that for school-age students the effects of teachers on value education begins and teachers fundtion as significant role models for students. This finding is consistent with the findings of the previous studies. For instance, Ishii (2010) found that teachers' caring behaviour, honesty, peaceful manner are significant part of an effective character education programs. Similarly, Veugelers (2000) found that in teaching values teachers are significant and they encourage students to acquire certain values. Ateş (2013) concluded whether consciously or unconsciously teachers are role model to students and therefore, they should reinforce positive values through this function. Can (2008) also concluded that teachers effectively make use of being model, empathy and value clarification in value education. Veugelers and Kat (2003) suggested that teachers should be aware of the fact that they are role models for students and should use this function to reinforce the values that are being taught. 
The participants suggested that value education should be either an independent course or certain values should be taught in existing courses. They also proposed that in value education case studies and drama can be used and that positive and desired behaviours and empathy should be encouraged among children. Therefore, teachers should be prepared for such functions. There are previous findings, which are consistent with the findings of the study. For instance, Çengelci (2010) analysed how value education is delivered in the fifth grade social studies courses. It was found that several distinct activites are used for value education, including case studies, example events, being models, certain days and weeks, , drama, actual events, empathy, association, relations with other courses, non-governmental organizations, parental involvement, and out of school activities. Johannson (2002) found that teachers employed empathy, using different perspectives, modelling, rewarding positive behaviors to teach ethical values. Tokdemir (2007) found that history teachers used case studies, narrations, demonstrations, empathy, projects, visits and observations in value education. Similarly, Akbaş (2004) concluded that teachers employed various methods in value education including stories, movies, drama, biography, drama, discussions.

The findings of the study also indicated that parental support contributes to value education at school and that there should be consistency between the value of parents and value education at school. Similarly, Baysal (2013) concluded that for teacher's parental support is very significant in value education. Deveci and Dal (2008) concluded based on the reports of classroom teachers that when values taught at school are not supported at home long-term behaviour modification cannot be achieved. Similarly, in the study by Yaşar and Çengelci (2009) parents argued that in value education they are very significant and they should be models for their children. Beldağ (2012) found that in acquiring values the parents play very significant role and that both teachers and parents should model for the children.

Another finding of the study is that the participants were not trained about how to deliver value education during the teacher training programs. They suggested that teachers can be informed about value education through in-service training courses. On the other hand, there is no obligatory course for value education in teacher training programs, but some programs have optional course about value education or character education. Previous findings are consistent with this finding of the study. For instance, Başçı (2012) concluded that teachers do not have necessary knowledge base about value education and how to deliver it and that teachers should be given an opportunity to fill this gap through quality seminars. Yalar (2010) also concluded that in-service trainin activities will be useful fot teachers to deliver value education. Fidan (2009) concluded that student teachers are not tained on values and how to teach values, indicating that they do not have enough information about value education. Thornburg (2008) found in a qualitative study that teachers do not have sufficient knowledge about value education.

Based on the findings of the study it is safe to argue that value education should be reconceptualised and reorganized taking into consideration the relationships between teachers, parents and society. For instance, with the cooperations of ministry of national education and higher education institutions campaigns can be organized concerning values to inform society. Teachers may take part in seminars on value education. Teacher training programs may include optional courses on value education in which micro teaching activities are used.

\section{References}

[1] Akbaş, O. (2004). Türk Milli Eğitim Sisteminin Duyuşsal Amaçlarının Illköğretim II. Kademedeki Gerçekleşme Derecesinin Degerlendirilmesi. Yayımlanmamış doktora tezi, Gazi Üniversitesi Eğitim Bilimleri Enstitüsü, Ankara.

[2] Arslan, M. (2007). Türk Eğitim Sisteminde Değerler Sorunu ve Eğitim Programlarına Yansıması, R. Kaymakcan, S. Kenan, H. Hökelekli, Z. Ş. Arslan, M Zengin (Editörler). Değerler ve Eğitimi. İstanbul. Değerler Eğitimi Merkezi Yayınları, 634-656.

[3] Ateş, F. (2013). Illkokul ve Ortaokul Öğretmenlerinin Değerler Eğitimi ve Uygulamalarına Yönelik Görüsleri Üzerine Nitel Bir Araşıırma. Yayımlanmamış Yüksek Lisans Tezi. Yeditepe Üniversitesi, Sosyal Bilimler Enstitüsü, İstanbul.

[4] Başçı, Z. (2012). Beşinci Sınıf Sosyal Bilgiler Dersinde Değer Eğitiminin Öğretmen Görüşlerine Göre İncelenmesi (Erzurum Örnegii). (Yayınlanmamış Doktora Tezi). Atatürk Üniversitesi Eğitim Bilimleri Enstitüsü.

[5] Baysal, N. (2013). Ortaokul Sosyal Bilgiler Derslerinde Değerler Eğitimi Uygulamalarının Öğretmenler Yönüyle Degerlendirilmesi. (Yayınlanmamış Yüksek Lisans Tezi). Niğde Universitesi, Eğitim Bilimleri Enstitüsü. 
[6] Beldağ, A. (2012). İlköğretim yedinci sınıf Sosyal Bilgiler dersindeki değerlerin kazanılma düzeyinin çeşitli değişkenler açısından incelenmesi (Erzurum ifi örneği). Yayımlanmamış doktora tezi. Atatürk Üniversitesi Eğitim Bilimleri Enstitüsü, Erzurum.

[7] Bridge, B. (2003). Etik Degerler Egitimi, Beyaz Yayınları, İstanbul, 2003.

[8] Bishop, A., FitzSimons,G., Seah, W.T. \& Clarkson, P. (1999, November- December). Values in Mathematics Education: Making Values Teaching Explicit in the Mathematics Classroom. Paper Presented at the Combined Annual Meeting of the Australian Association for Research in Education and the New Zealand Association for Research in Education. Melbourne, Australia.

[9] Can, Ö. (2008): Dördüncü ve Besinci Sınıf Öğretmenlerinin Sosyal Bilgiler Dersinde Değerler Eğitimi Uygulamalarına Iliş̧kin Görüşleri. Yayımlanmamış yüksek lisans tezi. Hacettepe Üniversitesi Sosyal Bilimler Enstitüsü, Ankara.

[10] Cohen, L., Manion, L., \& Morrison, K. (2007). Research Methods in Education. London: Routledge/ Falmer.

[11] Creswell, J. W. (2012). Educational research: Planning, conducting, and evaluating quantitative and qualitative research (Fourth edition). New Jersey: Pearson Education, Inc.

[12] Creswell, J.W. \& Plano Clark, V. C. (2014). Karma Yöntem Araştırmaları Tasarımı ve Yürütülmesi. Ankara: Anı Yayıncllik.

[13] Cengelci (2010). Illköğretim beşinci sınıf Sosyal Bilgiler dersinde değerler eğitiminin gerçekleştirilmesine ilişkin bir durum çalışması. Anadolu Unniversitesi Eğitim Bilimleri Enstitüsü, Eskişehir.

[14] Deveci, H. ve Dal, S. (2008). Primary School Teacers' Opinions on the Efficacy of Social Studies Program in Value Gain, Humanity \&Social Science Journal, 3(1), 1-11.

[15] Fasheh, M.(1982). Mathematics, Culture, and Authority. For the Learning of Mathematics, 3(2), 2-8.

[16] Fidan, N. K. (2009). Öğretmen adaylarının değer öğretimine ilişkin görüşleri. Kuramsal Eğitim Bilim Dergisi, 2(2), 118.

[17] Güngör, E. (1998). Ahlak psikolojisi ve sosyal ahlak. Ötüken Yayınevi, İstanbul.

[18] Ishii, M. (2010). Implementing Character Education At Public Schools, Focusing On Sathya Sai Education In Human Values: A Case Study Of Sathya Sai School, LeIcester, U.K. And India. Unpublished doctoral thesis of education. San Francisco, California, United States.

[19] Johansson, E. (2002). Morality in preschool Interaction: Teachers' strategies for working with children"s morality. Early child development and care, 172(2). 203-221.

[20] Kılıç Şahin, H. (2010). İlköğretim okullarında Sosyal Bilgiler dersini yürüten 4. ve 5. Sınıf öğretmenlerinin sosyal bilgüler dersi ögrețim programında yer alan değerlerin kazandırılmasına ilişkin görüşleri. Yayımlanmamış yüksek lisans tezi, Gazi Universitesi Eğitim Bilimleri Enstitüsü, Ankara.

[21] Lucas, L. D. (2009). Character Education as Perceived and Implemented by Selected Middle School Teachers of One Rural County in West Virginia. Unpublished doctoral thesis of education. Dissertation Submitted to the College of Human Resources and Education. West Virginia University. Morgantown, West Virginia, United States.

[22] Merriam, Sharan B. (2013). Qualitative Research-A Guide to Design and Implementation. Çev. Edit. S. Turan. Ankara: Nobel Akademik Yayıncllik.

[23] Miles, M. B. \& Huberman, A.M. (1994). Qualitative data analysis : an expanded sourcebook. (2nd Edition). Calif.: SAGE Publications.

[24] Özalp-Kaplan, N. (2014). Illkokullarda değer eğitiminin öğretmen görüşlerine göre değerlendirilmesi. (Yayınlanmamış Yüksek Lisans Tezi). Mustafa Kemal Universitesi, Sosyal Bilimler Enstitüsü.

[25] Özdaş, F. (2013). Ortaokullarda Değerler Eğitimi ve İstenmeyen Öğrenci Davranışlarına Illiškin Öğretmen Görüşlerinin Degerlendirilmesi. (Yayınlanmamış Doktora Tezi). Fırat Universitesi,'Eğitim Bilimleri Enstitüsü.

[26] Robinson-Lee, W. (2008). A framework for understanding character education in middle schools. Unpublished doctoral thesis, Walden University.

[27] Sağnak, M. (2004). Örgütlerde değerler yönünden birey-örgüt uyumu ve sonuçları. Kuram ve Uygulamada Eğitim Yönetimi, 10 (37), 72-95. 
[28] Schreiber, J. B. \& Asner-Self, K. (2011). Educational research. The interrelationship of questions, sampling, design, and Analysis. NJ: John Wiley \& Sons, Inc.

[29] Seah, W. T. (2002).Exploring Teacher Clarification of Values Relating to Mathematics Education. Horwood (Eds.), Valuing Mathematics in Society, 93-104. Brunswick, Australia: Mathematical Association of Victoria.

[30] Seah, W. T. \& Bishop, A.J. (2000). Values in Mathematics Textbooks: A Wiew Throught The Australasian Regions. Paper Presented at the Annual Meeting of the American Educational Research Association, New Orleans, LA.

[31] Swadener, M. \& R. Soedjadi, R. (1988). Values, Mathematics Education and the Task of Developing Pupils' Personalities: An Indonesian Perspective. Educational Studies In Mathematics. 19 (2), 193-208.

[32] TDK, Türk Dil Kurumu. Güncel Türkçe Sözlük. 28 Haziran 2016 Tarihinde http://www.tdk.gov.tr adresinden erişildi.

[33] Thornburg, R. (2008). The lack of professional knowledge in values education. Teaching and Teacher Education. 24, 1791-1798.

[34] Tokdemir, M. A. (2007). Tarih Öğretmenlerinin Değerler Ve Değer Eğitimi Hakkındaki Görüşleri. Yayımlanmamış Yüksek Lisans Tezi. Karadeniz Teknik Universitesi Sosyal Bilimler Enstitüsü, Trabzon.

[35] Veugelers, W. (2000). Different ways of teaching values. Educational Review, 25, 37-46.

[36] Veugelers, W. and Kat, E. (2003). Moral task of the teacher according to students, parents and teachers. Educational Research and Evaluation, 9(1), 75-91.

[37] Yalar, T. (2010). Illköğretim Sosyal Bilgiler Programında Değerler Eğitiminin Mevcut Durumunun Belirlenmesi ve Oğretmenlere Yönelik Bir Program Modülü Geliştirme. Yayımlanmamış doktora tezi. Mersin Üniversitesi Sosyal Bilimler Enstitüsü, Mersin.

[38] Yaşar, S. ve Çengelci, T. (2009). 'Views of students' parents regarding values education in primary education in Turkey." Paper presented at International Conference on Primary Education, Hong Kong.

[39] Yılmaz, K. (2010). Devlet ortaöğretim okullarında görev yapan öğretmenlerin örgütsel adalet algıları. Kuram ve Uygulamada Eğitim Bilimleri, 10(1), 579-616.

\section{Tables}

Table 1. Theme, sub themes and categories about values education

\begin{tabular}{|c|c|c|}
\hline Theme & Sub theme & Categories \\
\hline \multirow{4}{*}{ Values education process } & Why early ages? & $\begin{array}{l}\text { Life preparation } \\
\text { Personality development } \\
\text { Permanence }\end{array}$ \\
\hline & Who are effective? & $\begin{array}{l}\text { Parents } \\
\text { Society } \\
\text { Teachers }\end{array}$ \\
\hline & What should be done? & $\begin{array}{l}\text { Inserting value education course into the program } \\
\text { Integration of value education with other courses } \\
\text { Using case studies } \\
\text { Parental involvement } \\
\text { Social projects } \\
\text { Out of school activities }\end{array}$ \\
\hline & What do the participants suggest? & $\begin{array}{l}\text { Teacher training programs } \\
\text { In-service training activities } \\
\text { Project and performance implications } \\
\text { Criterias for choosing teachers }\end{array}$ \\
\hline
\end{tabular}

